\title{
ARHGEF28 wt Allele
}

National Cancer Institute

\section{Source}

National Cancer Institute. ARHGEF28 wt Allele. NCI Thesaurus. Code C97266.

Human RGNEF wild-type allele is located in the vicinity of $5 q 13.2$ and is approximately 316 $\mathrm{kb}$ in length. This allele, which encodes Rho-guanine nucleotide exchange factor protein, plays a role in the modulation of integ rin and growth factor receptor signaling. 